JURNAL PENJAMINAN MUTU

LEMBAGA PENJAMINAN MUTU

INSTITUT HINDU DHARMA NEGERI

DENPASAR

\title{
BETWEEN COST CHEAP PRICES AND INCREASING HIGH QUALITY EDUCATIONAL UNIVERSITY IN PEKANBARU CITY
}

\author{
by \\ Prama Widayat \\ Universitas Lancang Kuning-Pekanbaru \\ pramawidayat@unilak.ac.id
}

Diterima 10 Desember 2017, direvisi 28 Januari 2018, diterbitkan 28 Pebruari 2018

\begin{abstract}
The need of higher education in the community has become the main thing for the future, not all can study at State Universities (PTN) but some must enter in Private Universities (PTS). But the problem that arises is the problem of tuition fees in the PTS course higher than the state university, the tendency of prospective students in choosing Higher Education (PT) based on cost and quality. While the problems from the PT side lies in the budget constraints in improving quality because of talk about the quality of course comprehensive from the means of lectures to the specialization of universities. Limitations of costs can at least be overcome by the synergy of universities, private companies and governments so it is not always student.
\end{abstract}

\section{Keyword : cost education and quality university}

\section{INTRODUCTION}

For municipal area Pekanbaru, the tuition average is $\mathrm{Rp} 2,500,000$ per semester for the private university (PTS), forthe prospective students, that tuitionis too much and they feel objectionwhen we refer to the side of UMR in 2016 from $\mathrm{Rp} 2.165 .435$ and this is higher than the other provinces such as West Sumatra and Jambi. But on the other hand, the university is really competing to give the cheaper tuition that is true contrary to the University that already has a standard tuition. Even so, it will take much better preliminary work.

The necessary for higher education at the University has become a necessity of the millennium era, regardless of whether to enter a state university (PTN) or private university (PTS). However, not all graduates of Senior High School can be accepted in PTN, so most of them are accommodated in PTS. In other words, most of them who enter the PTS is an escape from the failure in PTN, although there are some students who choose PTS because the quality is not much different from the PTN or even better in terms of quality.

The consequence to enter in private university is they have higher tuition than PTN, because in PTN they use subsidy system, where the tuition is adjusted to the parent's income. Each province or city has a diversity in terms 
of educational costs, higher cost not qualified yet or otherwise low cost does not necessarily has a less good quality. It means that there are two sides to the contrary because the cost is not always due to the determinants of the quality of education, but this cannot be ignored in this digitalization era. Investment in education also cannot be ignored to improve the quality. The high cost of education is not only happen in Indonesia but Bangladesh also has this problem, Ashraf (2017: 136) stated that, in Bangladesh is also experiencing the high cost of education but now they are making improvements with the decrease in educational costs.

The education sector is not about social activities butit was flowed in the business sector and this cannot be denied for them who are in the business of education. It is not vulgar to run a business purely but still has limits on the value of education, Gouws (2017: 107) stated that, the authority should be consider for the cost to improving quality that changes over time. Internal party should think about how to maximize the available funds that changes at any time.

Increase the cost of education with the reasons for better quality, amidst of the economic conditions of the community who areunstable, it is not a good things even though PTS actually need a budget for quality improvement. Sometimes these qualities are seen in the end of educational result, it is connect to the various dimensions that exist in the process (Ibrahim, 2017: 262). The digitalization era, force for every university must applies this process from upstream to downstream and this requires a higher cost. Veloutsou (2004: 170) stated that, the university must provide the data and easily accessible for another people who are needed. Especially for the prospective of university students that need a lot of information, like: accreditation of university, the tuition, the equipment, the available major, the superiority that they have and different from other PTS.
So, all of this information must be available by online.

In the end, the cost of education will increase gradually and with adjustable quantities, some cities that has private university outstanding and has quality that already consciously will automatically easy to recruit new students, but how about the other universitythat does not have a name to show their "quality". Our society is still sensitive when we talking about the cost of education and they will compare with some PTS in the same city, they must think"we do not need to choose the expensive university, if the cheaper one is the same quality". Need the intelligence of the PTS to get around the business competition between the cheaper tuition and has a good quality.

\section{DISCUSSION}

The ability of a university in improving the quality of teaching tailored to the internal capacity both in terms of finance, human resources and strategies that must be apply. But, not only a private university that has good accreditation is more desirable by prospective students, but also the university that has lower accreditation is more desirable by prospective students in determining their choice where they want to continue their undergraduate studies.

Sometimes the fruit of simalakama between the needs of quality improvement with financial limitations, Larrán (2015: 265) stated that, barriers often faced by one of them is funding problems. But if this is used as a reason, of course they will not give space for PTS to advance and improve competitiveness, there is a way in every limitations.

\subsection{Tuition fees}

The limitation economic of the family becomes a factor for a child to continuing their education, fortunate for some students who get the scholarship from government or private but the problem is the number of scholarship is 
certainly not balanced with the number of students who will be awarded a scholarship. For families who live in poverty they prefer to fulfil their main necessary rather than to support their child to continue their education in university especially. Most of the poor families are from parents with low education, it can be seen in National BPS data from 2014 to 2017:

In table 1 above can be seen that the higher the education of a head of the household the less likely the poverty of the household, so this is the role of education is so important.

The higher education of a head of household it can be less likely the poverty of the household, this is the role of education that it is so important.But not everyone can afford to get an education in university because of the high tuition constraints. This is not only happened in Indonesia, Checchi (2000: 199) stated that, in the Italian state, if their parents have a lower education, their children are less likely to go to the higher education because of family factors, in this case education factor, income, and occupation are so dominant socially.

In abroad University, ethnic factors is also become a consideration in choosing a university. Ivy (2010: 401) stated that, ethnic factors influence in choosing a college, where white ethnic is free in choosing university, while Pakistan and African Asian are influenced by factors family. In the domestic, family factor means that there is a family who live near the campus so that if something happens to the child then that families can help. In addition, if there is a family of graduates from that Private University (PTS) then he would recommend it to other families.

Family factors become the smallest choice in determining the choice of Private University

Table 1. Character of Poor Household Based on the Education of Family Head

\begin{tabular}{lcccc}
\hline Education & $\mathbf{2 0 1 4}$ & $\mathbf{2 0 1 5}$ & $\mathbf{2 0 1 6}$ & $\mathbf{2 0 1 7}$ \\
\hline Not Complete SD & $40,57 \%$ & $40,81 \%$ & $37,81 \%$ & $37,44 \%$ \\
Complete SD & $37,89 \%$ & $39,78 \%$ & $37,12 \%$ & $37,46 \%$ \\
SMP & $12,33 \%$ & $10,45 \%$ & $13,13 \%$ & $13,52 \%$ \\
SMA & $8,56 \%$ & $8,47 \%$ & $10,88 \%$ & $10,86 \%$ \\
PT & $0,65 \%$ & $0,59 \%$ & $1,06 \%$ & $0,73 \%$ \\
\hline
\end{tabular}

Table 2. Considerations on Selecting Private Universities

\begin{tabular}{llcc}
\hline No & Alasan Memilih & Jumlah & Persentase \\
\hline 1 & Tuition fees & 118 & $35 \%$ \\
2 & Quality and Accreditation & 83 & $25 \%$ \\
3 & lecture facilities & 52 & $16 \%$ \\
4 & Website & 37 & $11 \%$ \\
5 & Promotion & 25 & $7 \%$ \\
6 & Spesialization & 15 & $4 \%$ \\
7 & Keluarga & 5 & $1 \%$ \\
\hline
\end{tabular}

Total $390 \quad 100 \%$


(PTS) because they prefer to be independent and do not want to distress the family

Based on our field research, using descriptive method by distributing random questionnaires to 390 students in Kota Pekanbaru on their consideration in choosing a college can be seen in table 2 below:

The student university who choose PTS based on the amount of tuition fees generally come from middle-lower income family finance. While, they are who choose PTS with the quality considerations, most of them come from middle-upper family finances. This data is still around Pekanbaru city and it can be different in every city in Indonesia, but here, we cannot be denied that the role of the cost cannot be ignored in determining the choice to choose PTS. This applies to regular class in morning and in the afternoon class for the employees, for the average class of employees earning them start from Rp 2,500,000 to Rp 3,500,000 per month. So, their consideration to determine the choice of PTS is theaffordable tuition fee. Currently, the private university tuition in Pekanbaru city ranges from $\mathrm{Rp} 2,000,000$ to Rp 3,000,000 per semester

\subsection{Quality and Accreditation}

The consideration of accreditation also cannot be considered from one of the eyes, because every university is required to have accreditation as a quality recognition, Cheng (2003: 210) stated that, college should be able to guarantee internal quality and provide future value, so that not only talk about current needs. Pham (2016: 387) stated that, it is required national accreditation standards to measure the quality of an educational institution. Srikanthan (2004: 278) stated that, institutional synergies are very needed to build a clear quality of education. In improving the quality, all the PTS wants this thing, but the obstacles cannot be ignored as stated by Odhiambo (2008: 428) mentions the most of obstacles of education world, is improving quality, improving efficiency, without raising the cost this professional development and the quality of education will be difficult to achieve.

Blanco-Ramírez (2014: 100) stated that, it is not enough just talking quality because it all depends on the process because quality issues and transnational accreditation have become a trending topic in the international world class. Keogh (1994: 31) also stated that, continuous improvement needs to be done to evaluate the existing quality so as to compete in a good manner.

Surpi (2017: 8) stated that, universities must always pay attention to quality in order to compete on global level, and Suci (2017: 6) also states, the performance of quality assurance has not been effective, which is caused by the politics of campus organization, actually politics is allowed, as long as it is objective in building quality. The quality of education is not only limited to the academic achievements that have been produced, but also how to provide excellent service to stakeholders, as mentioned by Angell (2008: 251) stated that, the quality of service provided is also an inseparable part of a process. maintaining the quality can not only rely on internal control but also is required external people in order to maintain the independence of the assessment, as Garwe's statement (2015: 396) in improving the quality of education, it is required external quality assurance. So psychologically, it will give the impression to stakeholders that the institution is prioritizing service and not just take their money for study in that institution. In Keskinen (2008: 649) also stated that, psychological factors determine a person in determining the choice of university. Thus the role of quality is a form of PTS application in improving accreditation as a form of world's recognition Higher Education world.

\subsection{Lecture facilities}

The other thing that is crucial is the availability of lecture facilities. Such as buildings, representative class rooms, complete of tables, 
chairs, air conditioners, projectors and whiteboards. All those things must be planned structurally and continually. Nir (2013: 119) said that, planning and infrastructure determine the effectiveness of the education process. Rymarzak (2015: 191) also said that, students are more looking at the availability of representative rooms to support the scientific activities. How lectures will run conducive in the room which is not representative, especially if the capacity exceeds standard of capacity, sometimes we still see the lecturing that is followed by more than 50 (fifty) students per room. This is not effective in providing comfort and concentration in the learning process.

Why there are classes that are over capacity?, the classical reason that is often heard is the availability of limited lecturers, do not want to open a new class because it will affect the increasing honorarium lecturer, there is no campus budget to pay additional fees for the class breaking, and veto leadership. This may not be common but is still happening in the world of higher education / some university, how can we talk about good results, while the process that is happened in the classroom is really not comfortable.

It also needs a modern library to support scientific development, Uwaifo (2007: 502), the need for automation in the library through computerization and this needs internal policies, funding capabilities and the ability of IT personnel. Khan (2015: 123) mentioned that, the needs of libraries also become supporting universities. Liu (2012: 100) university development in science and technology support the creation of campus' entrepreneurship. It means that the ability of the PTS to provide ITbased library development is absolutely done by the digital era competition.

\subsection{Access Information to University Website}

The progress of IT in this millennium era demands every institution including the world of education to provide disclosure information to the public, the public monitor the development of a PTS (University) from the website. So, PTS must provide all the information needed to influence the readers to decide their choice. Not just academic information but also other information, such as scholarships, extracurricular activities, cooperation with private companies, health insurance for students, the location of the PTS, because the location is also one of consideration for women. It is appropriate with the Joseph statement (1997: 18) women tending to choose universities based on location and this is different from the men who do not attach importance to the location of universities, social programs undertaken by private universities (PTS) should also be delivered as a form of society service and this thing is also stated by Plungpongpan (2016: 585) sometimes the general public sees the university's social activities from media or from other people as a consideration for determining college choice.

\subsection{Promotion of print and electronic media}

Promotion that is undertaken by the Private University (PTS) is not a guarantee to increase the number of students but it becomes a part that cannot be separated from the process of introducing the campus to the society, Nagel (1997: 101) said that, the need for a consumerbased approach to know consumer's desires that is also the needs of prospective students. Hanssen (2017: 755) Higher Education Institution (HEI) is used to recruit outstanding students from each school so there is satisfaction for prospective students by appreciating their intelligence. This is what is mentioned by Marketing Education without eliminating the identity of education itself.

Brown (2007: 321) there is a campus that sells openly because the demand is very high, then passive marketing through the utilization of communication via the internet, so it can be accessed by anyone. Yamamoto (2006: 567) 
said that, the need for a marketing process to provide the image of the campus to the society, thus thing reflect the value of the campus to the general public. Dao (2015: 675) stated that, the marketing process also can influence candidate of students in choosing a college, for post-graduate is more sensitive to the cost of college while they, who are still undergraduate category is determined by the income of parents.

Promotion does not have to through print and electronic media because it also can promote through Facebook, Instagram, Twitter and other social media because the activities of the virtual world cannot be ruled out to enter the market segment of the younger generation because most of them are not like reading print and electronic data. In addition, the campus must also pay an expensive cost for promotion in printing, so for minimizing the cost, alternative promotions in social media can be a consideration of the campus to convey any positive messages about their Private Universities (PTS).

\subsection{Specialization}

Competition of the labor also impacts on the wishes of candidate of students university, in choosing a credible Private Universities (PTS) and have something different from other Private Universities (PTS), Lenton (2013: 237) stated that, the determinants of the lectures are on a wider curriculum (especially about the vocational choice). Tsinidou (2010: 242) also said that, curriculum structure is needed to direct the students to the specialization that is desired by the students so that the graduates are good career prospects. They will choose the specialization, they will never think about fees anymore, because no matter how much they will pay as long as they get special skills, such as tax specialists, professional accountants, entrepreneurship etc.

Actually, building a specialization is not easy, there are some obstacles, Blake (2000:
68) stated that, most internal problem happened is inconsistencies, quality of teaching staff and wrong change strategies. Motwani (1997: 135) application of TQM in improving the quality of teaching. Gushchina (2010: 495) said that, unsolved issues are increasing competitiveness, labor market needs with labor itself, university specialization, technical specialization, commercialization of higher education and including those students who come from families that have low income. Moody (2007: 368) stated that, The Environmental Literacy Requirement (ELR) is needed to promote the campus environment and can be incorporated into the campus curriculum.

Reyes (2016: 153) said that, in Singapore, there is an entrepreneurial university that achieves the goals by transferring technology. The value of a Private University will be higher if it is able to transfer technology to support the entrepreneurial-based campus.

\section{CONCLUSION}

It cannot be denied, that the cost and quality factors become the dominant consideration for candidate of students' university in determining the choice of Private University (PTS), besides the limited cost owned by Private University (PTS), on the other hand improvement of quality also need attention. So this is a challenge, where the ability of private universities (PTS) to take advantage of the resources available, of course Private Universities (PTS) must measure all the internal potential that is owned, before doing cooperation with external People.

It is not talking limitations anymore, but they have to be able to use the limitations to do better, not always have to burden the students with the fees that very expensive, but Private University (PTS) can make cooperation with some private companies and also with the government in building educational institutions because the synergy of various elements into the special needs in the future, success is not 
alone, but able to collaborate with others and can complete each other, that is the real quality of success.

\section{BIBLIOGRAPHY}

Angell, Robert J., Troy W. Heffernan, Phil Megicks. Service quality in postgraduate education. Quality Assurance in Education, Volume: 16 Issue: 3, 2008.

Ashraf, Mohammad A., Abu Zafar Rashed Osman., Sarker Rafij Ahmed Ratan. Determinants of qualityeducation in private universities from student perspectives: A case study in Bangladesh. Quality Assurance in Education, Volume: 24 Issue: 1, 2016.

Blanco-Ramírez, Gerardo., Joseph B. Berger. Rankings, accreditation, and the international quest for quality: Organizing an approach to value in higher education. Quality Assurance in Education, Volume: 22 Issue: 1, 2014.

Blake, David., Jenny Lansdell. Quality in initial teacher education. Quality Assurance in Education, Volume: 8 Issue: 2, 2000 .

Brown, Claire., Peter Varley., John Pal. University course selection and services marketing. Marketing Intelligence \& Planning, Volume: 27 Issue: 3, 2009

Checchi, Daniele. University education in Italy. International Journal of Manpower, Volume: 21 Issue: 3/4, 2000.

Cheng, Yin Cheong. Quality assurance in education: internal, interface, and future. Quality Assurance in Education, Volume: 11 Issue: 4, 2003.

Dao, Mai Thi Ngoc., Anthony Thorpe. What factors influence Vietnamese students' choice of university. International Journal of Educational Management, Volume: 29 Issue: 5, 2015.

Garwe., Evelyn Chiyevo. Student voice and quality enhancement in higher education. Journal of Applied Research in Higher Education, Volume: 7 Issue: 2 , 2015.

Gouws, D.G., H.P. Wolmarans. Quality cost in tertiary education: Making internal failure cost visible. Meditari Accountancy Research Vol. 102002 : 87-108.

Gushchina, Elena. Factors, criteria, and determinants of the increase in the effectiveness of university education in Russia. International Journal of Educational Management, Volume: 24 Issue: 2, 2010.

Hanssen, Thor-Erik Sandberg., Gisle Solvoll. The importance of university facilities for student satisfaction at a Norwegian University. Facilities, Volume: 33 Issue: 13/14, 2015.

Ibrahim, Yaro., Rozita Arshad., Dani Salleh. Stakeholder perceptions of secondary educationquality in Sokoto State, Nigeria. Quality Assurance in Education, Volume: 25 Issue: 2, 2017.

Ivy, Jonathan. Choosing futures: influence of ethnic origin in university choice. International Journal of Educational Management, Volume: 24 Issue: 5, 2010.

Joseph, Mathew., Beatriz Joseph. $\underline{\text { Service }}$ quality in education: a student perspective. Quality Assurance in Education, Volume: 5 Issue: 1, 1997.

Khan, Ghalib., Rubina Bhatti. Determinants of academic law libraries' use, collections, and services among the faculty members: a case study of University of Peshawar. Collection Building, Volume: 34 Issue: 4, 2015. 
Keogh, William. The Role of the Quality Assurance Professional in DeterminingQuality Costs. Managerial Auditing Journal, Volume: 9 Issue: 4, 1994.

Keskinen, Esko., Juhani Tiuraniemi., Anna Liimola. University selection in Finland: how the decision is made. International Journal of Educational Management, Volume: 22 Issue: 7, 2008.

Larrán Manuel., Javier Andrades. Determining factors of environmental education in Spanish universities. International Journal of Sustainability in Higher Education, Volume: 16 Issue: 2, 2015.

Lenton, Pamela. Routes to educational success for low achievers.Journal of Economic Studies, Volume: 40 Issue: 2 , 2013.

Liu, Ye. Does entrepreneurial university really exist in China?: A case from Huazhong University of Science and Technology. Journal of Knowledge-based Innovation in China, Volume: 4 Issue: 2, 2012.

Moody, Gwyneth L., Peter G Hartel. Evaluating an environmental literacy requirement chosen as a method to produce environmentally literate university students. International Journal of Sustainability in Higher Education, Volume: 8 Issue: 3, 2007.

Motwani, Jaideep., Ashok Kumar. The need for implementing total quality management in education. International Journal of Educational Management, Volume: 11 Issue: 3, 1997.

Nir, Adam E., Bhojraj Sharma Kafle. The effect of political stability on public educationquality. International Journal of Educational Management, Volume: 27 Issue: 2, 2013.
Odhiambo, George. Elusive search for qualityeducation: The case of quality assurance and teacher accountability. International Journal of Educational Management, Volume: 22 Issue: 5, 2008.

Pham, Huong Thi., Louise Starkey. Perceptions of higher educationquality at three universities in Vietnam. Quality Assurance in Education, Volume: 24 Issue: $\underline{3}, 2016$.

Plungpongpan, Jirawan., Leela Tiangsoongnern., Mark Speece. University social responsibility and brand image of private universities in Bangkok. International Journal of Educational Management, Volume: 30 Issue: 4, 2016.

Reyes., Charisse N. Framing the entrepreneurial university: the case of the National University of Singapore. Journal of Entrepreneurship in Emerging Economies, Volume: 8 Issue: 2, 2016.

Rymarzak, Malgorzata., Dariusz Trojanowski. Asset management determinants of Polish universities. Journal of Corporate Real Estate, Volume: 17 Issue: 3, 2015.

Suci, A. (2017). PENJAMINAN MUTU PERGURUAN TINGGI: DILEMA POLITIK ORGANISASI DAN URGENSI PENGGUNAAN PROFESIONAL EKSTERNAL. Jurnal Penjaminan Mutu, 3(2), 215-222.

Surpi, N. K. (2017). HADAPI TANTANGAN GLOBAL, LEMBAGA PENDIDIKAN HINDU HARUS JADI GURUKULA MODERN. Jurnal Penjaminan Mutu, 3(2), 171-179.

Srikanthan, G., John Dalrymple. A synthesis of a quality management model for education in universities. International Journal of Educational Management, Volume: 18 Issue: 4, 2004. 
Tsinidou, Maria., Vassilis Gerogiannis., Panos Fitsilis. Evaluation of the factors that determine quality in higher education: an empirical study. Quality Assurance in Education, Volume: 18 Issue: 3, 2010.

Uwaifo, Stephen Osahon. Age and exposure to computers as determinants of attitudes of librarians towards automation in Nigerian universities. Library Review, Volume: 56 Issue: 6, 2007.

Veloutsou, Cleopatra., John W. Lewis., Robert A. Paton. University selection: information requirements and importance. International Journal of Educational Management, Volume: 18 Issue: 3, 2004.

Yamamoto, Gonca Telli. University evaluation selection: a Turkish case. International Journal of Educational Management, Volume: 20 Issue: 7, 2006.

Nagel, Tove., Tone Kvernbekk. $\underline{\text { A dialogue }}$ about the quality of education. Quality Assurance in Education, Volume: 5 Issue: $\underline{2}, 1997$. 